\title{
Prenatal diagnosis and genetic counselling
}

\author{
D. J. H. BROCK \\ From the University Department of Human Genetics, Western General Hospital, Edinburgh
}

Traditionally genetic counselling has been made up of two parts. The first is the establishment of an accurate diagnosis of the disorder, usually in the child of the parents availing themselves of counsel but sometimes in the consultand himself. The second is the calculation of recurrence risks through knowledge or the best possible assumptions about the mode of inheritance of the disease. When the counsellor has made the diagnosis and stated the risks, he may provide further guidance on the severity of the disorder and the likely burden to the family concerned and, if necessary, he may advise on contraceptive methods, adoption, or artificial insemination. But the decision to proceed with a family or curtail reproduction lies with the parents.

The advent of prenatal diagnosis has changed this traditional mode in a number of situations. The ability to detect an inborn error of metabolism, chromosome disorder, or congenital malformation in utero early enough to allow termination of pregnancy has added a new dimension to genetic counselling. In place of confronting parents with the choice of planning further children in full knowledge of high risk of abnormality or limiting their families, it is now possible in a rapidly growing number of disorders to monitor at-risk pregnancies and ensure that children born will not be affected. In a sense this has added a positive element to the former inherent negativeness of genetic counselling. The limitations-if the ethical problems which termination of pregnancy may present to parents are overcome-lie in the technology of prenatal diagnosis: the safety of amniocentesis, the problem of growing amniotic fluid cells, the use of amniotic fluid itself, the number of disorders which may be detected in utero in the early stages of gestation, the certainty of diagnosis, and the extension of the list of disorders capable of diagnosis. This review will be concerned primarily with these facets of prenatal diagnosis, already the subject of several comprehensive reviews (Nadler, 1972; Emery, 1973; Milunsky, 1973).

\section{Amniocentesis}

The technique and complications of amniocentesis have been recently reviewed (Scrimgeour, 1973a). The optimal time appears to be 14 to 16 weeks of gestation, with the mode of entry transabdominal rather than transvaginal and with prior localization of the placenta by ultrasound strongly recommended. Reported mortality and morbidity rates are extremely low; Scrimgeour (1973a) has reviewed 529 amniocenteses before 20 weeks without maternal or fetal death and a reported failure rate (grossly bloody or no fluid) of $3.6 \%$. Milunsky (1973) has reported on 298 consecutive amniocenteses from his laboratory in which there were 11 miscellaneous complications, including four abortions, one fetal death, and one stillbirth. It is quite possible that complications have been underreported. The possibilities of isoimmunization following fetomaternal haemorrhage have yet to be adequately assessed.

\section{Amniotic Fluid Cell Culture}

Many reports have appeared in the literature of successful amniotic fluid cell cultures. The criterion for success is usually a primary outgrowth and the ability to report a karyotype. Nadler and Gerbie (1970) recorded a $97 \%$ success rate on 160 samples while more recently Milunsky (1973) was successful with 201 out of 211 samples $(96 \%)$. If biochemical analysis is to be carried out on the cultured cells the problem is a more difficult one, for in most types of biochemical determination several million cells are needed and this means a number of subcultures. In addition to the problem of persuading the cells to grow in the first place, the biochemist may have to deal with cultures which degenerate before the requisite number of cells is obtained. There is not a great deal of information on 'biochemical success rates', but where reported (table I) such studies show a comparatively high number of failures. Perhaps more important is the relatively long interval between amniocentesis and the time at which a biochemical result is obtained. If the optimum for amniocentesis is at 16 weeks of pregnancy and the mean time to a biochemical result 39.5 days (Sutherland and Bain, 1973), any termination required will have to be carried out 


\begin{tabular}{lllll}
\hline $\begin{array}{l}\text { Gestation } \\
\text { (weeks) }\end{array}$ & No. of Cultures & $\begin{array}{l}\text { Success } \text { Rate } \\
(\%)\end{array}$ & $\begin{array}{l}\text { Time } \\
\text { (weeks) }\end{array}$ \\
\hline $13-15$ & 21 & 76 & $4-7$ & References \\
$16-18$ & 45 & 85 & $4-9$ & Uhlendorf (1970) \\
$19-21$ & 16 & 75 & $4-11$ & Uhlendorf $(1970)$ \\
$21-23$ & 21 & 86 & $4-9$ & Shlendorf (1970) \\
\hline
\end{tabular}

Table I Amniotic fluid cell culture for biochemical analysis

some time after 22 weeks. A failure of cell growth may well occur too late to allow repeat amniocentesis.

A possible answer to this problem lies in the use of microtechniques for enzymatic assay. Richardson and Cox (1973) have described a method for growing colonies of fibroblasts from amniotic fluid cells in individual wells of a tissue culture plate. They were able to measure hypoxanthine-guanine phosphoribosyl transferase activity and determine the electrophoretic pattern of hexosaminidase after a median period of 14 days when colony size ranged from 2000 to 8000 cells. Hösli (1973) has brought microtechniques to an even finer point; he claims that after as few as seven days' growth some two dozen metabolic errors are detectable on 25 cells or less.

A problem in the development of microtechniques may well be the heterogeneity of cultured amniotic fluid cells. Two types of cell have been clearly recognized-a short-lived epithelial-like cell and a longer-lived fibroblast-like cell (Steele and Breg, 1966). The morphology of these two cell types differs considerably; less is known of the biochemistry. Melancon, Lee, and Nadler (1971) found histidase activity in epithelioid cells but not in fibroblast-like cells which suggests that there may be other enzymatic differences. As long as amniotic fluid cells were being grown through serial subcultures any enzymatic difference between the cell types was probably unimportant because only the more robust fibroblasts survived. But with microtechniques and rapid analyses, differences in the comparative enzymology of the different cell types could be critical.

The occasional observation of macrophages in amniotic fluid cell culture (Nadler and Gerbie, 1970; Uhlendorf, 1970) has been disturbing in that they have appeared to be of maternal type. Recently Sutherland, Brock, and Scrimgeour (1973) have reported on the appearance of fetal macrophages in early cultures from anencephalic pregnancies and suggested that this might form the basis of a diagnostic test. It is not yet clear whether fetal macrophages will be found in other abnormal pregnancies or to what extent they might distort the kind of enzyme assays envisaged by Hösli.

\section{Amniotic Fluid}

The considerable difficulties experienced in the reliable and consistent growth of amniotic fluid cells has led to consideration of amniotic fluid itself as a medium for antenatal diagnosis. There seems little doubt that most of the protein of the fluid is serum type and maternal in origin throughout pregnancy (Sutcliffe and Brock, 1973), though there are important contributions from a variety of enzymes, some of which have a fetal origin (Sutcliffe and Brock, 1972). Lower molecular weight metabolites may turn over a great deal faster than do proteins, so that there will be some difficulty in using their concentrations to detect fetal abnormality. Nonetheless the earliest use of amniotic fluid in monitoring genetic disease was through bilirubin concentrations in cases of rhesus incompatibility. Spectrophotometric determination at $450 \mathrm{~nm}$ either with (Liley, 1961) or without (Bevis, 1952) correction for other metabolites is the commonest method, though chemical techniques have also been described. Erythroblastosis fetalis is usually diagnosed in the third trimester of pregnancy through serially rising bilirubin concentrations. Likewise in the adrenogenital syndrome (a collection of inborn errors of metabolism involving steroid hydroxylases), antenatal diagnosis either by amniotic fluid pregnanetriol levels or maternal urinary oestriol seems more reliable late in pregnancy (Merkatz, New, Peterson, and Seaman, 1969). However, in both these conditions treatment in utero appears both possible and effective.

In those disorders where the severity of the disease calls for termination of pregnancy, the role of amniotic fluid analysis is more controversial (table II). Nadler and Messina (1969) originally suggested that Pompe's disease could be diagnosed through amniotic fluid $\alpha$-glucosidase. This was contested (Cox, Douglas, Hutzler, Lynfield, and Dancis, 1970) and it is now accepted that the amniotic fluid enzyme has properties quite different from those found in cultured amniotic fluid cells (Salafsky and Nadler, 1971; Sutcliffe and Brock, 1972) and that is should never be used to monitor for Pompe's disease. 


\begin{tabular}{lll}
\hline Disorder & Metabolite or Enzyme Analysed & References \\
\hline Rh incompatibility & Bilirubin & Bevis (1952) \\
Adrenogenital syndrome & Pregnanetriol & Jeffcoate et al (1965) \\
Methylmalonic acidaemia & Methylmalonic acid & Morrow et al (1970) \\
Hurler's, Hunter's, Sanfilippo disease & Mucopolysaccharides & Matalon et al (1970) \\
Argininosuccinic aciduria & Argininosuccinic acid & Goodman et al (1973) \\
Tay-Sachs disease & Hexosaminidase A & O'Brien et al (1971) \\
Sandhoff's disease & Hexosaminidase A and B & Desnick et al (1973) \\
Generalized gangliosidosis & B-Galactosidase & Lowden et al (1973) \\
Metachromatic leucodystrophy & Arylsulphatase A & Borresen and Van der Hagen (1973) \\
I-cell disease & Lysosomal enzymes & Huijing et al (1973) \\
Myotonic dystrophy & Secretor phenotype & Schrott et al (1973) \\
\hline
\end{tabular}

Table II The use of amniotic fluid in antenatal diagnosis

In the mucopolysaccharidoses the situation is less clear. Matalon, Dorfman, Nadler, and Jacobson (1970) diagnosed Hurler's syndrome at 14 weeks of gestation on the basis of high total acid mucopolysaccharides and an abnormal proportion of heparan sulphate in the fluid. Brock, Gordon, Seligman, and Lobo (1971) reported a case in which normal acid mucopolysaccharides and no heparan sulphate in the fluid had resulted in a child with Hurler's syndrome, and recently Matalon, Dorfman, and Nadler (1972) have revised their opinion of the safety of such chemical analyses in the antenatal diagnosis of mucopolysaccharidoses. However, it has been suggested that a detailed qualitative analysis of the different mucopolysaccharides of the fluid may be a useful adjunct to or even substitute for the more reliable sulphate uptake studies on cultured cells (Crawfurd, Dean, Hunt, Johnson, MacDonald, Muir, Payling Wright, and Payling Wright, 1973). Since the specific enzyme defects are now known in Hurler's, Hunter's, Sanfilippo, and Schcie syndromes it is possible that direct enzymatic determinations on the fluid may contribute toward antenatal diagnosis of these conditions.

In a number of other disorders involving defects of degradative mechanisms located in the lysosomal fraction of the cell, eg, Tay-Sachs disease, Sandhoff's disease, generalized gangliosidosis, and metachromatic leucodystrophy-the specific enzymes appear to be absent or low in the fluid (table II). In I-cell disease, on the other hand, a number of lysosomal enzymes are strongly elevated (Huijing, Warren, and McLeod, 1973) and it is possible that hexosaminidases, already known to reflect fetal rather than maternal state through studies on Tay-Sachs and Sandhoff's diseases, might be used in antenatal diagnosis.

In myotonic dystrophy, a late-onset dominant, the basic protein defect remains obscure. What is known, however, is that the genetic locus for myotonic dystrophy is linked to that governing secretor status, and that the secretor phenotype of a fetus can be determined from samples of amniotic fluid. But because secretor phenotype is a dominant character only a minority of all possible marriages will be informative. The affected parent must be heterozygous for secretor and the state of coupling or repulsion between secretor and the myotonic gene known, which means the phenotyping of at least one grandparent. Even then, when all these conditions have been satisfied, the possibility of recombination reduces the certainty to $92 \%$. Nonetheless, this linkage has been used to reassure a pregnant woman with myotonic dystrophy that her child would be normal (Schrott, Karp, and Omenn, 1973). It must be noted that in this particular case (assuming secretor determinations were correctly made) the child still has an $8 \%$ chance of being affected, because of recombination.

\section{Prenatal Diagnoses Already Made}

As yet only comparatively few prenatal diagnoses have been made, though a considerable range of metabolic disorders have been covered. The widest experience has probably been gained in Tay-Sachs disease (Milunsky, 1973), in part because there is a clearly identifiable population at risk, and also because community programmes have been launched to tackle this disorder (Kaback, 1973). Tay-Sachs disease is a sphingolipidosis, and this group of disorders has yielded most readily to antenatal diagnosis (table IIIa), probably because the responsible enzymes are ubiquitously distributed and easy to measure. Most of the assays have been carried out on cultured cells, but in a growing number of cases amniotic fluid itself has been used (table II).

Apart from the sphinogolipidoses a highly miscellaneous group of disorders has been tackled (table IIIb). Enzymatic assay on cultured amniotic fluid cells is the method of choice. However, in Pompe's disease electron microscopic examination of glycogen accumulation in lysosomes has been made both in uncultured (Hug, Schubert, and 


\begin{tabular}{|c|c|c|}
\hline Disorder & Enzyme Deficiency & Reference \\
\hline Generalized gangliosidosis, types 1 and 2 & $\beta$-Galactosidase & $\begin{array}{l}\text { Kaback et al (1973) } \\
\text { Lowden et al (1973) } \\
\text { Booth et al (11973) }\end{array}$ \\
\hline Tay-Sachs disease $\left(G_{2}\right.$ gangliosidosis type 1$)$ & Hexosaminidase A & $\begin{array}{l}\text { Schneck et al (1970) } \\
\text { O'Brien et al (1971) }\end{array}$ \\
\hline $\begin{array}{l}\text { Sandhoff's disease }\left(\mathrm{GM}_{2} \text { gangliosidosis type } 2\right) \\
\text { Fabry's disease } \\
\text { Gaucher's disease }\end{array}$ & $\begin{array}{l}\text { Hexosaminidase } \mathbf{A} \text { and } \mathbf{B} \\
\text { Ceramide trihexosidase } \\
\text { Glucocerebrosidase ( } \beta \text {-glucosidase) }\end{array}$ & $\begin{array}{l}\text { Desnick et al }(1973) \\
\text { Brady et al }(1971) \\
\text { Schneider et al }(1972) \\
\text { Epstein et al }(1972)\end{array}$ \\
\hline $\begin{array}{l}\text { Niemann-Pick disease } \\
\text { Krabbe's disease } \\
\text { Metachromatic leukodystrophy }\end{array}$ & $\begin{array}{l}\text { Sphingomyelinase } \\
\text { Galactysol ceramide } \beta \text {-galactosidase } \\
\text { Arylsulphatase A }\end{array}$ & $\begin{array}{l}\text { Epstein et al (1971) } \\
\text { Suzuki et al (1971) } \\
\text { Van der Hagen et al (1973) }\end{array}$ \\
\hline
\end{tabular}

Table IIIa Antenatal diagnoses of sphingolipidoses

\begin{tabular}{|c|c|c|}
\hline Disorder & Enzyme or Metabolite Abnormality & References \\
\hline Pompe's & $\begin{array}{l}\text { Acid maltase ( } \alpha \text {-glucosidase); lysosomal } \\
\text { glycogen }\end{array}$ & $\begin{array}{l}\text { Nadler and Messina (1969) } \\
\text { Hug et al (1970) }\end{array}$ \\
\hline Galactosaemia & Galactose-1-phosphate uridyl transferase & Nadler (1968) \\
\hline Maple syrup urine disease & Branched chain $\alpha$-ketoacid decarboxylase & Nadler and Gerbie (1970) \\
\hline Homocystinuria & Cystathionine synthetase & Uhlendorf (1970) \\
\hline Argininosuccinic aciduria & Argininosuccinase & $\begin{array}{l}\text { Jacoby et al (1973) } \\
\text { Goodman et al (1973) }\end{array}$ \\
\hline Propionic acidaemia & Propionyl-CoA carboxylase & Gompertz et al (1973) \\
\hline Methylmalonic acidaemia & Methylmalonic acid & Morrow et al (1970) \\
\hline $\left.\begin{array}{l}\text { Hurler's syndrome } \\
\text { Hunter's syndrome }\end{array}\right\}$ & $\begin{array}{l}\text { Radioactive sulphate uptake into mucopoly- } \\
\text { saccharides; mucopolysaccharide analysis of } \\
\text { amniotic fluid }\end{array}$ & $\begin{array}{l}\text { Fratantoni et al (1969) } \\
\text { Matalon et al (1970) } \\
\text { Brock et al (1971) } \\
\text { Matalon et al (1972) }\end{array}$ \\
\hline Acid phosphatase deficiency & Lysosomal acid phosphatase & Nadler and Egan (1970) \\
\hline Cystinosis & Cystine incorporation & Schulman et al (1970) \\
\hline Lesch-Nyhan syndrome & $\begin{array}{l}\text { Hypoxanthine-guanine phosphoribosyl } \\
\text { transferase }\end{array}$ & $\begin{array}{l}\text { Fujimoto et al (1968) } \\
\text { De Mars et al (1969) } \\
\text { Boyle et al (1970) }\end{array}$ \\
\hline
\end{tabular}

Table IIIb Antenatal diagnoses of other disorders

Soukup, 1970) and in cultured cells (Nadler, Bigley, and Hug, 1970). In Hurler's and Hunter's syndromes the excessive incorporation of radioactive sulphate into the dermatan sulphate and heparan sulphate fractions of the intracellular mucopolysaccharides has been used, though there is no reason now why the deficient enzymes should not be directly measured. In cystinosis the accumulation of cystine in cultured cells has been used to diagnose heterozygosity in a fetus at risk and thus allow a pregnancy to continue.

\section{Congenital Malformations}

According to Milunsky (1973), chromosomal disorders occur in about 1 in 200 live births, inborn errors of metabolism at about 1 in 100, and major congenital abnormalities at 1 in 30 to 1 in 50 live births. In the vast majority of congenital abnormalities both the molecular pathology and environmental versus hereditary component of the disorder is entirely obscure. Nonetheless recurrence risks often lie between 5 and $10 \%$, affording an identifiable population at risk for prenatal detection.

Approaches to early diagnosis of congenital defects have taken a number of lines. At the moment two show promise; the use of ultrasound in the measurement of the biparietal diameter of the fetal and therefore in the detection of anencephaly, microcephaly, and hydrocephaly (Campbell, 1969) and the use of $\alpha$-fetoprotein concentrations in the diagnosis of spina bifida and anencephaly (Brock and Sutcliffe, 1972). Ultrasound has already been used to detect anencephaly (Campbell, Johnstone, Holt, and May, 1972; Thiery, Van Kets, Yo Le Sian, de Hemptinne, Vrijens, and Chef, 1973) but it is not yet reliable before about 20 weeks, nor will it detect spina bifida. $\alpha$-Fetoprotein has been used before 20 weeks for both spina bifida (Brock and Sutcliffe, 1972; Allan, Ferguson-Smith, Donald, Sweet, and Gibson, 1973) and anencephaly (Brock and Scrimgeour, 1972; Lorber, Stewart, and Ward, 1973). There also seems a possibility that a proportion of these central nervous system malformations 
will be diagnosable through $\alpha$-fetoprotein levels in maternal serum early in pregnancy (Brock, Bolton, and Monaghan, 1973).

\section{Prospects and Limitations}

Up to now many of the limitations of prenatal diagnosis have been methodological, in particular, the difficulty of amniocentesis, of amniotic fluid cell culture, and of microtechniques in enzyme assay. As these problems are solved, another type of limitation becomes more apparent, the problem of diagnosing a disorder whose molecular pathology is not expressed in the constituents of the amniotic fluid. Sickle-cell anaemia, phenylketonuria, and haemophilia, for example, are three comparatively common inborn errors of metabolism where the basic protein lesion is known, but where the prospect of prenatal diagnosis remains distant. The relevant enzyme for phenylketonuria, phenylalanine hydroxylase, is expressed only in liver cells, while factor VIII (deficient in haemophilia) is measurable only in plasma. In sickle-cell anaemia there is a double problem; the difficulty of getting samples of fetal blood early in pregnancy, and if this is achieved, the further difficulty of measuring the small amount of $\beta$-chain-containing haemoglobin at that stage of pregnancy.

Two new approaches offer some hope of solving these problems. The first is fetoscopy, the direct visualization of the fetus with a fibreoptic telescope (Scrimgeour, 1973b). In time it should be possible to couple fetoscopy to fetal blood sampling or solid tissue biopsy, so that the most appropriate tissue for biochemical analysis can be used. The second is somatic cell hybridization, the interspecific or intraspecific fusion of different lines of cells followed by culture of the resulting heterokaryons. If amniotic fluid cells were to be 'hybridized' with cells from other tissues, it might be possible to unlock some of the normally repressed genes of the amniotic fluid cell nucleus.

\section{References}

Allan, L. D., Ferguson-Smith, M. A., Donald, I., Sweet, E. M., and Gibson, A. A. M. (1973). Amniotic-fluid alpha-fetoprotein in the antenatal diagnosis of spina bifida. Lancet, 2, 522-525.

Bevis, D. C. A. (1952). The antenatal prediction of haemolytic disease of the newborn. Lancet, 1, 395-398.

Booth, C. W., Gerbie, A. B., and Nadler, H. L. (1973). Intrauterine detection of $\mathrm{GM}_{1}$-gangliosidosis, type 2. Pediatrics, 52 , 521-524.

Børresen, A. L., and van der Hagen, C. B. (1973). Metachromatic leukodystrophy. III. Direct determination of amylsulphatase A activity in amniotic fluid. Clin. Genet., 4, 442-446.

Boyle, J. A., Raivio, K. A., Astrin, K. H., Schulman, J. D., Graf, M. L., Seegmiller, J. E., and Jacobson, C. B. (1970). LeschNyhan syndrome: preventive control by prenatal diagnosis. Science, 169, 688-689.

Brady, R. O., Uhlendorf, B. W., and Jacobson, C. B. (1971). Fabry's disease: antenatal detection. Science, 172, 174-175.
Brock, D. J. H., Bolton, A. E., and Monaghan, J. M. (1973). Prenatal diagnosis of anencephaly through maternal serum alphafetoprotein measurement. Lancet, 2, 923-924.

Brock, D. J. H., Gordon, H., Seligman, S., and Lobo, E. (1971). Antenatal detection of Hurler's syndrome. Lancet, 2, 1324-1325-

Brock, D. J. H., and Scrimgeour, J. B. (1972). Early prenatal diagnosis of anencephaly. (Letter) Lancet, 2, 1252-1253.

Brock, D. J. H., and Sutcliffe, R. G. (1972). Alpha-fetoprotein in the antenatal diagnosis of anencephaly and spina bifida. Lancet, 2, 197-199.

Campbell, S. (1969). Ultrasonic fetal cephalometry during the second trimester of pregnancy. J. Obstet. Gynaec. Brit. Cwlth, 77, 1057-1063.

Campbell, S., Johnstone, F. D., Holt, E. M., and May, P. (1972). Anencephaly: early ultrasonic diagnosis and active management. Lancet, 2, 1226-1227.

Cox, R. P., Douglas, G., Hutzler, J., Lynfield, J., and Dancis, J. (1970). In-utero detection of Pompe's disease. Lancet, 1 , 893.

Crawfurd, M. d'A., Dean, M. F., Hunt, D. M., Johnson, D. R., Macdonald, R. R., Muir, H., Paying Wright, E. A., and Payling Wright, C. R. (1973). Early prenatal diagnosis of Hurler's syndrome with termination of pregnancy and confirmatory findings on the fetus. J. med. Genet., 10, 144-153.

DeMars, R., Sarto, G., Felix, J. S., and Benke, P. (1969). LeschNyhan mutation: prenatal detection with amniotic fluid, cells. Science, 164, 1303-1305.

Desnick, R. J., Krivit, W., and Sharp, H. L. (1973). In utero diagnosis of Sandhoff's disease. Biochem. Biophys. Res. Commun. $51,20-24$.

Emery, A. E. H. (1973). Antenatal Diagnosis of Genetic Disease. Churchill Livingstone, Edinburgh and London.

Epstein, C. J., Brady, R. O., Schneider, E. L., Bradley, R. M., and Shapiro, D. (1971). In utero diagnosis of Niemann-Pick disease. Amer. J. hum. Genet., 23, 533-535.

Epstein, C. J., Schneider, E. L., Conte, F. A., and Friedman, S. (1972). Prenatal detection of genetic disorders. Amer. J. hum Genet., 24, 214-226.

Fratantoni, J. C., Neufeld, E. F., Uhlendorf, B. W., and Jacobson, C. B. (1969). Intrauterine diagnosis of the Hurler and Hunter syndromes. New Engl. J. Med., 280, 686-688.

Fujimoto, W. Y., Seegmiller, J. E., Uhlendorf, B. W., and Jacobson, C. B. (1968). Biochemical diagnosis of an X-linked disease in utero. (Letter) Lancet, 2, 511-512.

Gompertz, D., Goodey, P. A., Thom, H., Russell, G., MacLean, M. W., Ferguson-Smith, M. E., and Ferguson-Smith, M. A. (1973). Antenatal diagnosis of propionicadaemia. (Letter) Lancet, 1, 1009-1010.

Goodman, S. I., Mace, J. W., Turner, B., and Garrett, W. J. (1973). Antenatal diagnosis of argininosuccinic aciduria. Clin. Genet., 4, 236-240.

van der Hagen, C. B., Børresen, A. L., Molne, K., Oftedal, G., Bjøro, K., and Berg, K. (1970). Metachromatic leukodystrophy. I. Prenatal detection of arylsulphatase A deficiency. Clin. Genet., 4 256-259.

Hösli, P. (1973). Microtechniques for rapid prenatal diagnosis in early pregnancy. In Proceedings of the 4th International Conference on Birth Defects, Vienna, September 1973. (Excerpta Medica Int. Congr. Ser., No. 297), pp. 13-14. Excerpta Medica Foundation, Amsterdam.

Hug, G., Schubert, W. K., and Soukup, S. (1970). Prenatal diagnosis of type II glycogenosis. Lancet, $1,1002$.

Huijing, F., Warren, R. J., and McLeod, A. G. W. (1973). Elevated activity of lysosomal enzymes in amniotic fluid of a fetus with mucolipidosis II (I-cell disease). Clin. chim. Acta, 44, 453-455.

Jacoby, L. B., Littlefield, J. W., Milunsky, A., Shih, V. E., and Wilroy, R. S. (1973). A microassay for argininosuccinase in cultured cells. Amer. J. hum. Genet., 24, 321-324.

Jeffcoate, T. N. A., Fliegner, J. R. H., Russell, S. H., Davis, J. C. and Wade, A. P. (1965). Diagnosis of the adrenogenital syndrome before birth. Lancet, 2, 553-555.

Kaback, M. M. (1973). Tay-Sachs disease: a model for prevention of genetic disease. In Proceedings of the 4th International Conference on Birth Defects, Vienna, September 1973. (Excerpta Medica Int. Congr. Ser., No. 297), p. 12. Excerpta Medica Foundation, Amsterdam.

Kaback, M. M., Sloan, H. R., Sonneborn, M., Herndon, R. M., and Percy, A. K. (1973). GM $_{1}$-gangliosidosis type 1 : In utero detecttion and fetal manifestations. J. Pediat., 82, 1037-1041. 
Lilev, A. W. (1961). Liquor amnii analysis in the management of the pregnancy complicated by rhesus sensitization. Amer.J. Obstet. Gynec., 82, 1359-1370.

Lorber, J., Stewart, C. R., and Ward, A. M. (1973). Alpha-fetoprotein in antenatal diagnosis of anencephaly and spina bifida. (Letter) Lancet, $1,1187$.

Lowden, J. A., Cutz, E., Conen, P. E., Rudd, N., and Doran, T. A.

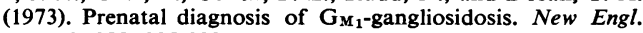
J. Med., 288, 225-228.

Matalon, R., Dorfman, A., and Nadler, H. L. (1972). A chemical method for the antenatal diagnosis of mucopolysaccharidoses. (Letter) Lancet, 1, 798-799.

Matalon, R., Dorfman, A., Nadler, H. L., and Jacobson, C. B. (1970). A chemical method for the antenatal diagnosis at mucopolysaccharidoses. (Letter) Lancet, 1, 83-84.

Melancon, S. B., Lee, S. Y., and Nadler, H. L. (1971). Histidase activity in cultured amniotic fluid cells. Science, 173, 627-628.

Merkatz, I. R., New, M. I., Peterson, R. E., and Seaman, M. P. (1969). Prenatal diagnosis of adrenogenital syndrome by amnioce.itesis. J. Pediat., 75, 977-982.

Milunsky, A. (1973). The Prenatal Diagnosis of Hereditary Disorders. Thomas, Springfield, Illinois.

Morrow, G., III, Schwarz, R. H., Hallock, J. A., and Barness, L. A. (1970). Prenatal detection of methylmalonic acidaemia. J. Pediat., 77, 120-123.

Nadler, H. L. (1968). Antenatal detection of hereditary disorders. Pediatrics, 42, 912-918.

Nadler, H. L. (1972). Prenatal detection of genetic disorders. Advanc. hum. Genet., 3, 1-37.

Nadler, H. L., Bigley, R. H., and Hug, G. (1970). Prenatal detection of Pompe's disease. (Letter) Lancet, 2, 369-370.

Nadler, H. L., and Egan, T. J. (1970). Deficiency of lysosomal acid phosphatase: a new familial metabolic disorder. New Engl. J. Med., 282, 302-307.

Nadler, H. L., and Gerbie, A. B. (1970). Role of amniocentesis in the intrauterine detection of genetic disorders. New Engl. J. Med., 282, 596-599.

Nadler, H. L., and Messina, A. M. (1969). In utero detection of type II glycogenosis (Pompe's disease). Lancet, 2, 1277-1278.

O'Brien, J. S., Okada, S., Fillerup, D. L., Veath, M. L., Adornato, B., Brenner, P. H., and Leroy, J. G. (1971). Tay-Sachs disease: prenatal diagnosis. Science, 172, 61-64.

Richardson, B. J., and Cox, D. M. (1973). Rapid tissue culture and microbiochemical methods for analyzing colonially grown fibroblasts from normal, Lesch-Nyhan and Tay-Sachs patients and amniotic fluid cells. Clin. Genet., 4, 376-380.

Salafsky, I., and Nadler, H. L. (1971). Alpha-1, 4-glucosidase activity in Pompe's disease. J. Pediat., 79, 794-798.
Schneck, L., Friedland, J, Valenti, C., Adachi, M., Amsterdam, D. and Volk, B. W. (1970). Prenatal diagnosis of Tay-Sachs disease. Lancet, 1, 582-584.

Schneider, E. L., Ellis, W. G., Brady, R. O., McCulloch, J. R: and Epstein, C. J. (1972). Infantile (type II) Gaucher's disease. in utero diagnosis and fetal pathology. J. Pediat., 81, 1134-1139.

Schrott, H. G., Karp, L., and Omenn, G. S. (1973). Prenatal prediction in myotonic dystrophy: guidelines for genetic counseling. Clin. Genet., 4, 38-45.

Schulman, J. D., Fujimoto, W. Y., Bradley, K. H., and Seegmiller, J. E. (1970). Identification of heterozygous genotype for cystinosis in utero by a new pulse-labeling technique: preliminary report. J. Pediat., 77, 468-470.

Scrimgeour, J. B. (1973a). Amniocentesis: technique and complications. In Antenatal Diagnosis of Genetic Disease, edited by A. E. H. Emery, pp. 11-39. Churchill Livingstone, Edinburgh and London.

Scrimgeour, J. B. (1973b). Other techniques for antenatal diagnosis. In Antenatal Diagnosis of Genetic Disease, edited by A. E. H. Emery, pp. 40-57, Churchill Livingstone, Edinburgh and London.

Steele, M. W., and Breg, W. R., Jr. (1966). Chromosome analysis of human amniotic fluid cells. Lancet, 1, 383-385.

Sutcliffe, R. G., and Brock, D. J. H. (1972). Observations on the origin of amniotic fluid enzymes. J. Obstet. Gynaec. Brit. Cwlth, 79, 902-910.

Sutcliffe, R. G., and Brock, D. J. H. (1973). Immunological studies on the nature and origin of the major proteins in amniotic fluid. J. Obstet. Gynaec, Brit. Cwlth, 80, 721-727.

Sutcliffe, R. G., Brock, D. J. H., Robertson, J. G., Scrimgeour, J. B., and Monaghan, J. M. (1972). Enzymes in amniotic fluid: a study of specific activity patterns during pregnancy. J. Obstet. Gynaec. Brit. Cwlth., 79, 895-901.

Sutherland, G. R., and Bain, A. D. (1973). Antenatal diagnosis of inborn errors of metabolism: tissue culture aspects. Humangenetik, 20, 251-255.

Sutherland, G. R., Brock, D. J. H., and Scrimgeour, J. B. (1973) Amniotic fluid macrophages and anencephaly. (Letter) Lancet, 2, 1098-1099.

Suzuki, K., Schneider, E. L., and Epstein, C. J. (1971). In utero diagnosis of globoid cell leukodystrophy. (Krabbe's disease). Biochem. Biophys. Res. Commun., 54, 1363-1366.

Thiery, M., van Kets, H., Yo Le Sian, A., de Hemptinne, D., Vrijens, M., and Chef, R. (1973). Early diagnosis of anencephaly. (Letter) Lancet, 1, 599-600.

Uhlendorf, B. W. (1970). Use of amniotic fluid and reliability of diagnosis procedures. In Early Diagnosis of Human Genetic Defects (Fogarty International Centre Proceedings No. 6, HEW Publication No. (NIH) 72-75) edited by M. Harris, pp. 149-168. 